\title{
HUBUNGAN ANTARA RELIGIUSITAS DENGAN DEATH ANXIETY: STUDI META ANALISIS
}

\author{
Muhammad Fakhrurrozi \\ Universitas Gunadharma
}

\begin{abstract}
Meta analysis applied to 12 studies has proved that religiosity overall relate to death anxiety signilicantly. Intrinsic religious prientation, one of religiosity's aspects has the biggest correlation coefficient than the four other aspects $(r=0-26)$. The following other four aspects are believe in life after death $(r=0.197)$, ritual $(r=0.149)$, the importance of religion $(0.061)$ and stage of religion ( $r=-0.004$ ). This meta analysis study findings shows that religiosity aspect is one of variables which has correlation to the dealh anxiely.
\end{abstract}

Key word: death anxiety, religiusitas

Penelitian yang berkaitan dengan terna death anxiety dan fear of death telah banyak dilakukan. Fortner dan Neirneyer (1999) pernah melakukan suatu review kuantitatif terhadap 49 buah hasil penefitian baik yang dipublikasikan maupun tidak tentang hubungan antara death anxiety dengan umur, integritas ego, gender, institusionalisasi, permasalahanpermasalahan fisik dan psikologis dan agama pada orang dewașa akhir. Hasil review tersebut menunjukkan bahwa orang dewasa yang memiliki integritas ego yang dan lemah, memiliki banyak permasalahan fisik dan psikologis cenderung memiliki kecemasan akan kematian yang tinggi. $\mathrm{Hal}$ yang sama juga dialami oleh mereka yang memiliki problem berkaitan dengan institusionalisasi. Review ini juga menyarankan agar dilakukan pengukuran secara khusus terhadap death anxiety dan melakukan sampling pada populasi dewasa akhir.

Review kuantitatif di atas menyebutkan banyak faktor yang bisa menimbulkan kecemasan akan kematian. Penelitian yang dilakukan oleh Chung dkk (2000) mencoba untuk mengungkap satu faktor saja yaitu permasalahan trauma psikologis. Chung dkk mencoba untuk meneliti tentang hubungan antara stres yang ditimbulkan oleh pengalaman traumatik dengan kecemasan akan kematian pada warga yang bertempat tinggal di sekitar terjadinya kecelakaan pesawat terbang of Coventry. Inggris. Subjek yang terlibat berjumlah 82 orang di mana mereka diharuskan mengisi Skala Pengaruh Kejadian. Kuesioner Kesehalan Umum (GHQ) dan Skala Kecemasan Akan Kematian. Berdasarkan skor GHQ diketahui sebanyak $57 \%$ diskor pada atau di atas cutoff point GHQ. Hal ini berarti mereka memiliki pikiran untuk dapat mengalami gangguan jiwa. Penelitian ini juga menunjukkan adanya hubungan antara pengaruh suatu kejadian, penderitaan psikologis dan kecemasan akan kematian.

Selain kecemasan, kematian juga berhubungan dengan ketakutan. Penelitian yang dilakukan oleh Florian dan Mikulincer (1997) mencoba untuk menguji hubungan antara kematian significant others dan ketakutan akan kematian pada orang dewasa. Ada dua kelompok subjek yang digunakan. Kelompok pertama terdiri dari 86 
orang yang mengalami kematian signif ucant others sedangkan kelompok kedua terdiri dari 86 orang yang tidak mengalami kematian significant others. Hasil penelitian menunjukkan bahwa kehilangan pada masa awal usia kanak-kanak berhubungan secara positif dengan komponen interpersonal dari ketakutan terhadap kematian. Hasil lainnya menunjukkan bahwa kehilangan yang dialami saat sekarang behubungan secara positif dengan komponen intrapersonal dan transpersonal dari fear of death. Hubungan tersebut dipengaruhi oleh identitas significant others yang meninggal, usia subjek saat kehilangan di masa awa anakanak dan gender. Studi tentang ketakutan pada kematian ini juga dicoba dihubungkan dengan pemaknaan kematian (death meaning).

Cicirelli (1998) mencoba menghubungkan kedua variabel tersebut pada orang dewasa dan mencoba melihat bagaimana pengaruh umur dan gender terhadapnya. Subjek yang terlibat sebanyak 265 mahasiswa (19 - 55 tahun) yang dibagi menjadi 2 kelompok yaitu usia 19 - 25 tahun (225 orang) disebut kelompok remaja dan usia 26-55 tahun (40 orang) disebut kelompok dewasa. Cicirell menggunakan 3 dimensi dari death meaning yaitu Extinction, Afterffie dan Legacy. Sedangkan fear of death diukur dengan Leming Fear of Death Scales (LSDF). Setelah dilakukan regresi diketahui bahwa kelompok remaja dan wanita memiliki ketakutan tehadap kematian yang lebih besar. Pada korelasi keduanya, hanya dimensi extinction yang berpengaruh secara signifikan terhadap 7 aitem LSDF, afterffe mempengaruhi 4 skor LSDF dan legacymempengaruhi 2 skor LSDF.

Salah satu dari variabel yang diduga berpengaruh terhadap death anxiety adalah religiusitas. Hasil studi Neimeyer dan Fortner (1997) serta Neimeyer dan Van Brunt (1995) (keduanya dalam Fortner \& Neimeyer, 1999) menunjukkan bahwa seseorang yang lebih religius, akan memiliki kecemasan terhadap kematian yang tinggi. Tapi temyata korelasi antara religiusitas dan death anxiely pada subjek lansia tidak berhasil ditemukan (Fortner \& Neimeyer, 1999). Adanya hasil yang belum jelas mengenai keterkaitan antara religiusitas dengan death anxiely inilah yang mendorong penulis untuk melakukan meta analisis terhadap hubungan antara death anxiety dengan religiusitas ini. Penulis berasumsi bahwa death anxiety berkorelasi negatif dengan religiusitas. Semakin tinggi skor religiusitas seseorang, maka semakin rendah skor kecemasan terhadap kematian. Demikian pula sebaliknya.

\section{METODE}

\section{Analisis Data}

Pendekatan psikometris dari Hunter dan Schmidt (1990) digunakan dalam meta analisis ini. Pendekatan ini mengestimasi korelasi populasi dengan mengoreksi korelasi hasil amatan dari artifak-artifak, misalnya sampling error, measurement error atau range restriction. Tipe ukuran efek yang digunakan adalah korelasi (r). Adapun jika dalam membaca nilai korelasi temyata tidak mendapatkan harga $r$ dan yang tersedia nilai t, f dan d maka nilai itu ditransformasikan menjadi $r$ melalui model persamaan $r$. Menurut Hunter dan Schmidt (1990) model persamaan transformasinya sebagai berikut:

$$
r=t\left(t^{2}+N-2\right)
$$

\section{Pemilihan Studi}

Penelusuran studi primer terhadap religiusitas dan death anxiety dilakukan melalui beberapa cara, antara lain dengan menggunakan jumal elektronik di Proquest (yang dilanggan oleh UGM dan Universitas Gunadarma) dan EBSCO (yang dilanggan UGM), browsing di search engine www.googlescholar.com serta korespondensi dengan penulis artikel dari jumal yang bersangkutan. Kata kunci yang digunakan adalah death anxiety dan refigiosity. Korespondensi yang penulis lakukan adalah dengan Prof. Robert Neimeyer dari University of Memphis, Amerika Serikat. Pertimbangan untuk melakukan korespondensi dengan Neimeyer adalah karena pada saat dalam proses penelusuran melalui internet, penulis sering menemukan nama Robert Neimeyer dalarn 
berbagai tulisan yang berkaitan dengan kematian. Oleh karena itu, penulis memutuskan untuk menghubungi via e-mail. Usaha ini membuahkan hasil. Neimeyer kemudian mengirimkan hard copy artikel ilmiahnya via pos kepada penulis. Melalui serangkaian usaha penelusuran tersebut, penulis mendapatkan sebanyak 35 hasil tulisan ilmiah di berbagai jurnal. Tetapi setelah diteliti, ternyata hanya ada 7 artikel yang bisa dilakukan meta analisis tehadap religiusitas dan death anxiety. Ketujuh artikel tersebut merupakan hasil penelitian dari tahun 1997-2005.

\section{HASIL}

Gambaran Umum Korelasi dan Reliabilitas Instrumen

Berdasarkan hasil studi yang dilakukan terhadap aspek religiusitas diperoleh statistik deskriptif pada tabel 1 bahwa secara keseluruhan koefisien korelasi sebelum dikoreksi nilai kesalahannya yaitu rerata korelasi untuk aspek religiusitas. terhadap death anxiety, sebagai berikut: orientasi religius instrinsik, $r=-0.16$, pentingnya beragama, $r=-0.065$, ritual, $r=-$ 0.083 , tingkat religiusitas $r=0$, percaya pada hidup setelah mati, $r=-0.175$. Hasil korelassi ini jika diteliti kesemuanya masuk ke dalam nilai konsistensi internal dari masing-masing kasus (lihat tabel 2).

Tabel 1. Statistik Deskriptif Koefisien Korelasi dan Reliabilitas instrumen

\begin{tabular}{|c|c|c|c|c|c|}
\hline $\begin{array}{l}\text { Variabel } \\
\text { independen }\end{array}$ & & Min & Maks & Rerata & SD \\
\hline Orientasi & a) & 70 & 130 & 90.33333 & 34,35598 \\
\hline Religius & b) & -0.62 & 0.31 & -0.16 & 0.46508 \\
\hline instrinsik & c) & 0.73 & 0.85 & 0.8 & 0.06245 \\
\hline Pentingnya & a) & 70 & 674 & 372 & 427.0925 \\
\hline \multirow[t]{2}{*}{ Beragama } & b) & -0.07 & -0.06 & -0.065 & 0.007071 \\
\hline & c) & - & - & - & - \\
\hline $\begin{array}{l}\text { Variabel } \\
\text { independen }\end{array}$ & & Min & Maks & Rerata & SD \\
\hline \multirow[t]{3}{*}{ Ritual } & a) & 130 & 674 & 402 & 384.6661 \\
\hline & b) & -0.18 & 0.01 & -0.08333 & 0.095044 \\
\hline & c) & - & 0.83 & - & - \\
\hline Tingkat & a) & 140 & 155 & 147.5 & 10.6066 \\
\hline \multirow[t]{2}{*}{ Rellglusitas } & b) & -0.07 & 0.07 & 0 & 0.098995 \\
\hline & c) & - & 0.8 & - & - \\
\hline Percaya & a) & 71 & 130 & 100.5 & 41.7193 \\
\hline Pada Hidup & b) & -0.25 & -0.1 & -0.175 & 0.106066 \\
\hline Setelah & c) & - & 0.83 & - & - \\
\hline Mati & & & & & \\
\hline
\end{tabular}

Keterangan; a) subyek $(\mathbf{N})$, b) konelasi $\mathbf{r}_{\mathrm{xy}}$ c) reliabilitas $\mathbf{r}_{\mathrm{xx}}$ 
Tabel 2. Rangkuman Ukuran Efok Can Koefisien Reliabilitas 12 Studi

\begin{tabular}{|c|c|c|c|c|}
\hline No. Studi & N & Karakteristik Subjek & $\mathrm{rXY}$ & $r_{x x}$ \\
\hline \multirow{3}{*}{1} & & Jemaah gereja, Kristen Kctholik & & \\
\hline & 130 & $S M A-\$ 3,22-\varepsilon 4$ & $6.6 \%$ & 0.83 \\
\hline & & Jemaah gereja, Kristen Katholik, & & \\
\hline \multirow[t]{2}{*}{2} & 130 & $S M A-53_{x} 22-84$ & -0.25 & 0.83 \\
\hline & & Prolestan, Katolik, Campuran. & & \\
\hline \multirow[t]{2}{*}{3} & 155 & Atheis $60-\bar{i} 0$ & -0.07 & 0.6 \\
\hline & & Protestan, Katolik, Yahudi, & & \\
\hline \multirow[t]{2}{*}{4} & 71 & Atheis & $0.3:$ & 0.85 \\
\hline & & Protestan, Katolik, Yahudi, & & \\
\hline 5 & 71 & Atheis & -0.1 & \\
\hline \multirow[t]{2}{*}{6} & 130 & Professional Health, Pelajar & -0.62 & 0.82 \\
\hline & & $\begin{array}{l}\text { islam, dari lingkungani akademik, } \\
\text { perusahaan, rumah tangga, i6- }\end{array}$ & & \\
\hline \multirow[t]{2}{*}{7} & 140 & 70 & 0.07 & \\
\hline & & Mahasiswa S1, Protestan, & & \\
\hline \multirow[t]{2}{*}{ B } & 70 & Katholik, lain-lain, 19-30 & -0.17 & 0.73 \\
\hline & & Mahasiswa $\$ 1_{x}$ Protestan, & & \\
\hline 9 & 70 & Katholik, lain-fain, 19-30 & -0.07 & \\
\hline 10 & 674 & Pensiunan, $71-82$ & -0.10 & \\
\hline No. Studi & $\mathbf{N}$ & Karakteristik Subjek & $\mathrm{rxr}$ & $r_{i n}$ \\
\hline 11 & 674 & Pensiunan $_{\mathrm{x}} 71-82$ & -0.08 & \\
\hline 12 & 674 & Pensiunan, $71-82$ & -0.06 & \\
\hline
\end{tabular}


Tabel 3. Rangkuman koefisien reliabilitas serta koreksi kesalahan pengukuran terhadap variabel independen.

\section{A. Orientasl Religius Instrinsik}

\begin{tabular}{|c|c|c|c|c|c|c|c|c|c|}
\hline \multirow{2}{*}{$\begin{array}{l}\text { No. } \\
\text { Sundi }\end{array}$} & \multirow[b]{2}{*}{ Ponslitit } & \multirow[b]{2}{*}{ Tohun } & \multicolumn{2}{|r|}{ Partidupen } & \multirow[b]{2}{*}{$r$} & \multicolumn{2}{|c|}{ Rellabillins } & \multicolumn{2}{|c|}{ Konelisi Kes Peng } \\
\hline & & & $\mathbf{N}$ & Karaktotath & & tix & $r_{m}$ & 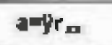 & beft \\
\hline (1) & (A) & (3) & $(4)$ & (b) & (5) & (7) & (6) & (9) & (10) \\
\hline B & $\begin{array}{l}\text { Swanson, J L. } 6 \\
\text { Byd, K.R. }\end{array}$ & 1997 & 70 & 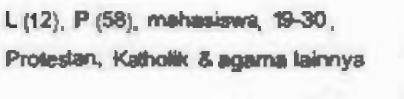 & -0.17 & 0.73 & DBO & oes4 & $0.9 \$ 1$ \\
\hline 4 & $\begin{array}{l}\text { Falkẹnhain. H, } \\
\text { Handal, P. J }\end{array}$ & 2003 & 71 & $\begin{array}{l}\text { L(17). P(54), 65-84, Photestent, } \\
\text { Kathe', Yahud Athais }\end{array}$ & 0.31 & 085 & 083 & 0.922 & 0.941 \\
\hline 6 & $\begin{array}{l}\text { Rofi, L L. } \\
\text { Buticeviciene, R, } 6\end{array}$ & & & $\begin{array}{l}\text { Perawat, Pellow, Dolder, Pelajer, Lain- } \\
\text { Lin }\end{array}$ & -0.62 & 0.82 & - & 0.906 & 0000 \\
\hline & Kenmaxk, D L. & 2002 & 130 & & & & & & \\
\hline & Jumlah & & 271 & & -0480 & 2400 & 1.680 & 2.682 & 1.822 \\
\hline
\end{tabular}

\section{B. Pentingnya Beragama}

\begin{tabular}{|c|c|c|c|c|c|c|c|c|c|}
\hline \multirow{2}{*}{$\begin{array}{l}\text { Mo } \\
\text { Syodi }\end{array}$} & \multirow[b]{2}{*}{ Pertertit } & \multirow[b]{2}{*}{ Tahun } & \multicolumn{2}{|r|}{ Partistipar } & \multirow[b]{2}{*}{$r$} & \multicolumn{2}{|c|}{ Reliabilitos } & \multicolumn{2}{|c|}{ Koreksi Kes Pung } \\
\hline & & & $\mathbf{M}$ & Karakdoristik & & rax & $r_{y r s}$ & $d=\bar{p} r_{k x}$ & $b+r_{m}$ \\
\hline (1) & (A) & (3) & (4) & (5) & (5) & $(7)$ & (9) & (9) & $(10)$ \\
\hline \multirow[t]{2}{*}{1} & $\begin{array}{l}\text { Harding.S.R., } \\
\text { Ftanelly } K \perp \text {. } \\
\text { Weaver, A J }\end{array}$ & & & 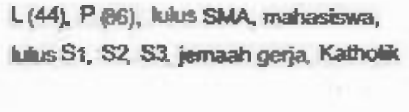 & 0.05 & nes & 076 & 0911 & 0.872 \\
\hline & Cosla KG. & 2005 & 130 & & & & & & \\
\hline \multirow[t]{2}{*}{$\pi$} & Duff, R.W.,8 & & & & -0.98 & - & - & 0000 & 0000 \\
\hline & Hing $L K$ & 1995 & 674 & 71-B2.pensiumen & & & & & \\
\hline \multirow[t]{3}{*}{11} & Dufi, R W. \& & & & & -0.08 & - & - & 0000 & 0000 \\
\hline & Hong.L. Kr & 1995 & 674 & T1-82, pentiumbin & & & & & \\
\hline & jumlth & & 80 & & -0170 & 0.830 & oreo & $0 . \$ 11$ & O.oTz \\
\hline
\end{tabular}

\section{Tingkat Religiusitas}

\begin{tabular}{|c|c|c|c|c|c|c|c|c|c|}
\hline \multirow{2}{*}{$\begin{array}{l}\text { Ha } \\
\text { Sundi }\end{array}$} & \multirow[b]{2}{*}{ Pensiltu } & \multirow[b]{2}{*}{ Tohun } & \multicolumn{2}{|r|}{ Pertletpin } & \multirow[b]{2}{*}{$r$} & \multicolumn{2}{|c|}{ Rallobilitas } & \multicolumn{2}{|c|}{ Koraksi Kes Pang } \\
\hline & & & $\mathbf{M}$ & Korriktoriatk & & ry & $r_{n}$ & $=9 r_{\mu n}$ & $b=y r_{t y}$ \\
\hline (1) & (2) & (B) & (4) & (5) & (6) & $(7)$ & (B) & (9) & $(10\rangle$ \\
\hline 7 & $\begin{array}{l}\text { Suhall } K, \text { a Alum, } \\
\text { s. }\end{array}$ & 2002 & 140 & 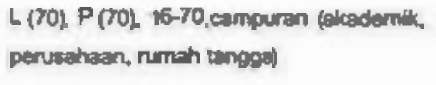 & 0.07 & - & 0.72 & 0000 & 0.8ng \\
\hline 3 & Wink, P. \& Scoth. J. & 2005 & 155 & $\begin{array}{l}\text { L(79), } P(82), 60-70, \text { Protesten (113), } \\
\text { Kotholih }(25), \text { Compuran (9), Atheis (9) }\end{array}$ & -0.07 & 0.80 & 0.81 & 0894 & 0900 \\
\hline & Jumlah & & 200 & & 0000 & aetoo & 1.830 & 0.894 & 1.749 \\
\hline
\end{tabular}




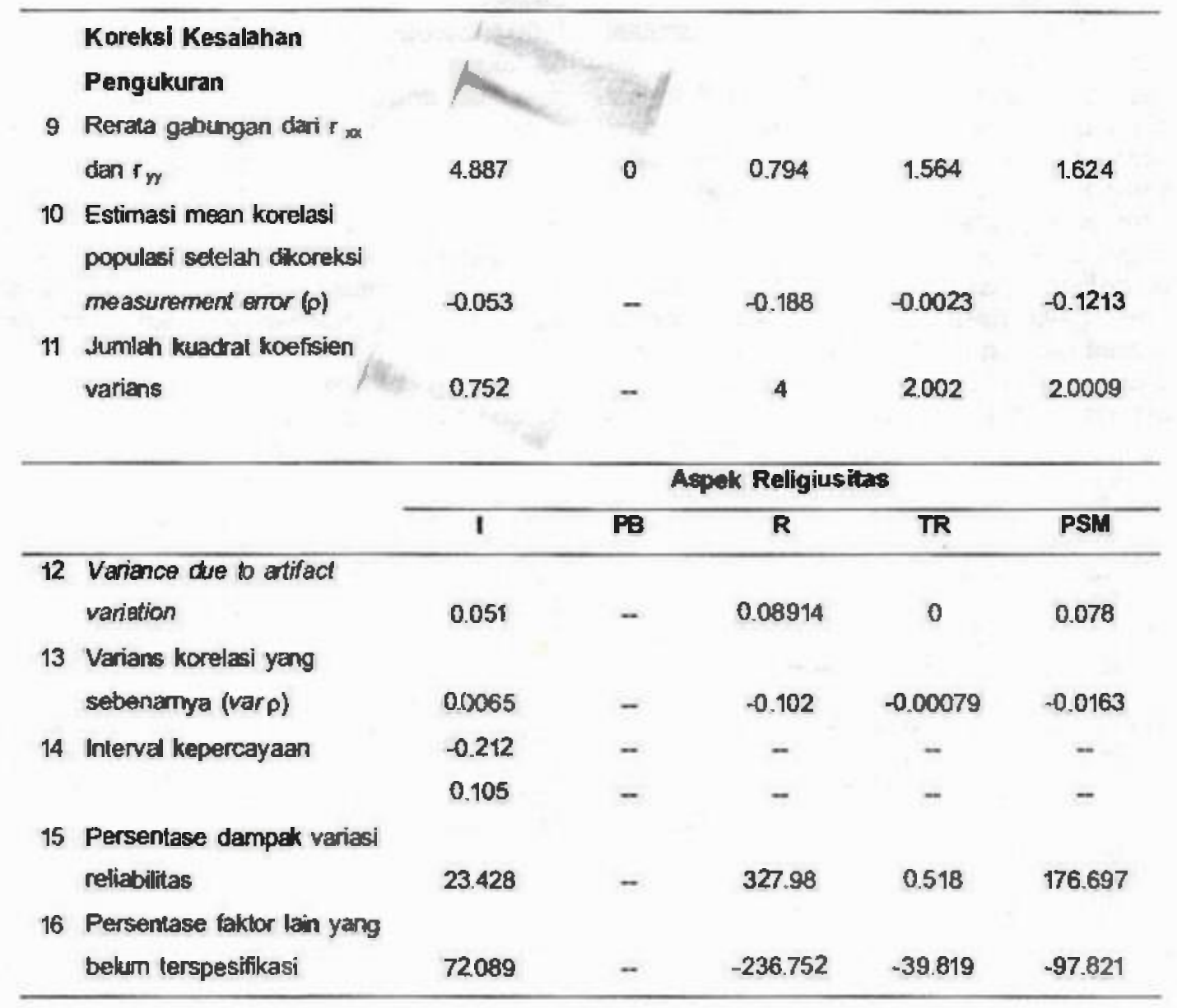

Keterangan: I = Orientasi Religinsitas Instrinsik, PB= Pentingnya Beragama, $\mathrm{R}=\mathrm{Ritua}$,

$\mathbb{T R}=$ Tingkat Religiusitas, $\mathrm{PSM}=$ Percaya Pada Hid 4 Setelah Mati

\section{Kore ks I artef ak penelitian}

\section{Orientasi Reilgius Instrinsik}

Hasil estimasi korelasi (ø) Orientasi Religiusitas Instrinsik yang didapatkan dari perhitungan adalah 0.260 dengan varians korelasi populasi ( $\left.{ }^{2}\right)$ senilai 0.217 . Adapun variansi yang disebabkan oleh kesalahan pengambilan sampel $\left({ }^{2}\right)=0.01$ dengan standar deviansi 0.455 . Dengan mempertimbangkan interval kepercayaan 95\% maka diperoleh range $1.153 \quad 6-0.243$ yang berarti ada korelasi negatif antara Orientasi Religiusitas Instrinsik dengan death anxiety. Pernyataan tersebut dapat diterima karena nilai korelasi seluruh studi masih dalam predikși di dalam batas interval kepercayaan. Sementara itu korelasi populasi sesungguhnya 0 setelah dikoreksi dengan kesalahan pengukuran sebesar 0.053 dan jika dilihat dari variansi korelasi populasi yang sebenarnya (var) sebesar 0.0065 . Interval kepercayaan dengan $95 \%$ maka koreksi kesalahan pengukuran diprediksi berkisar antara $0.212 \quad 0.105$ Presentasi kesalahan pengambilan sampel sebesar $4.694 \%$ sehingga terdapat faktor lain yang belum terspesifikasi sebesar $95.517 \%$ dan kesalahan pada pengukuran $23.428 \%$ serta faktor lain yang belum terspesifikasi sebesar $72.089 \%$. Hal itu berarti kesalahan pengambilan sampel dan kesalahan pengukuran kecil. 


\section{Pentingnya Beragama}

Estimasi rerała korelași populasi pada variabel Pentingnya Beragama, yaitu sebesar 0.061 , dengan varians korelasi populasi sebesar 0.004 . Sedangkan variasi yang disebabkan kesalahan pengambilan sampel sebesar 0.003. Rentang pada interval kepercayaan $95 \%$ menunjukkan angka $0.124 \cdot 0.056$. Berdasarkan rentang tersebut, dapat disimpulkan bahwa Pentingnya Beragama berkorelasi secara negatif dengan death anxiety. Hal itu dapat dikarenakan nilai korelasi pada seluruh stud berada dalam rentang interval tersebut. Akan tetapl besar variasi yang disebabkan kesalahan pengambilan sampel sangat besar yaitu $255.563 \%$. Faktor lain yang belum terspesifikasi dalam pengambilan sampel ini sebesar $28.124 \%$.

\section{Ritual}

Pada tabel koreksi artifak penelitian dapat dilihat bahwa variabel Ritual memiliki rerata korelasi populasi sebesar 0.149 dengan varians korelasi populasi sebesar 0.027 . Variansi sampling errordidapat nilai 0.002 dengan SD 0.157 . Pada interval kepercayaan $95 \%$ diketahui rentangnya adalah $0.157 \quad 0 \quad-0.458$. Dengan demikian korelasi keseluruhan pada studi ritual dengan death anxiety ini dapat diterima karena nilai korelasi varibel Ritual ini berada dalam rentang interval tersebut. Hasil fersebut juga menunjukkan adanya korelasi negatif antara ritual dengan death anxigty. Presentasi variansi yang disebabkan kesalahan pengambllan sampel cukup kecil yaitu sebesar $9.615 \%$. Faktor lain yang belum terspesifikasi sebesar $91.229 \%$ Namun demikian presentasi dari dampak variasi reliabilitasnya cukup besar yaitu $327.98 \%$ dan faktor lain yang belum terspesifikasi pada kesalahan pengukuran sebesar $236.752 \%$. Pada aspek ini juga diketahui estimasi rerata korelasi populasi setelah dikoreksi measurement error sebesar 0.188 dengan besar varians korelasi yang sebenamya yaitu 0.102 .

\section{TingkatReligiusitas}

Pada aspek ini didapat estimasi rerata korelasi populasi sebesar 0.004 dengan varians 0.005 . Selain itu juga diketahui varians sampling error sebesar 0.007. Berdasarkan interval kepercayaan 95 $\%$ didapat batas atas estimasi korelasi populasi yang studah dikoreksi sampling error sebesar0.01. Berdasarkan koreksi artifak ini, aspek ini tidak bisa disimpulkan apakah tingkat religiusitas berkorelasi dengan death anxiety. Karena tidak diketahui batas bawah nilai estimasi korelasi populasinya. Koreksi ini juga menunjukkan hasil bahwa terdapat varianis yang disebabkan oleh sampling errorsebesar $354.444 \%$ dan terdapat faktor lain yang belum terspesifikasi sebesar $39.301 \%$. Estimasi mean korelasi populasi setelah dikoreksi measurement error sebesar 0.0023 dengan varians korelasi yang sebenarnya sebesar 0.00079 . Persentasi dampak variasi reliabilitasnya yaitu sebesar $176.697 \%$ dan faktor lain yang belum terspesifikasikan yaitu $97.821 \%$.

\section{Percaya Pada Hidup Setelah Mati}

Tabel 3 menunjukkan. aspek Percaya Pada Hidup Selelah Mati memiliki rerata korelasi populasi sebesar 0.197 dengan varians sebesar 0.044 . Varians sampling error-nya sebesar 0.009 dengan SD 0.186 . Range yang didapat dari interval kepercayaan sebesar $95 \%$ yaitu $0.562 \varnothing$ 0.179 . Berdasarkan range tersebut nilai korelasi aspek Percaya Pada Hidup Setelah Mati ini berkorelasi negatif dengan death anxiety, karena berada dalam batas range interval kepercayaan tersebut. Selain itu, terdapat variansi yang disebabkan oleh sampling error yang cukup kecil yaitu 26.782 $\%$ dan faktor lain yang belum terspesiffikasi sebesar $78.876 \%$. Koreksi artifak pada aspek Perca ya Pada Hidup Setelah Mati juga menghasilkan nilai estimasi mean korelasi populasi setelah dikoreksi kesalahan pengukuran sebesar 0.1213 dengan varians korelasi yang sebenamya sebesar 0.0163. Presentase dampak variasi reliabilitasnya Cukup besaryaitu $176.697 \%$ dan faktor lain yang belum terspesifikasi sebesar $97.821 \%$.

\section{PEMBAHASAN}

Berdasarkan hasil meta analisis terhadap hubungan antara religitusitas dengan death anxiety, didapat hasil bahwa aspek religiusitas secara umum memiliki 
hubungan negatif yang signifikan dengan death anxiety. Artinya semakin tinggi religiusitas seseorang maka kecemasan terhadap kematiannya semakin rendah. Demikian juga sebaliknya.

Dari kelima aspek religiusitas dalam studi ini, orientasi religiusitas instrinsik tampaknya memifiki korelasi yang paling besar dibandingkan empat aspek tainnya ( $r=$ -0.26 ). Urutan besar korelasi empat aspek berikutnya adalah percaya pada hidup setelah mati $(r=-0.197)$, ritual $(r=-0.149)$, pentingnya beragama $(r=-0.061)$ dan tingkat religiusitas $(r=-0.004)$. Hașil ini sesuai dengan hasil review tehadap subjek berusia muda, yang menunjukkan bahwa seseorang yang lebih religius, akan memiliki kecemasan terhadap kematian yang tinggi (Neimeyer \& Fortner, 1997; Neimeyer \& Van Brunt, 1995 dalam Fortner \& Neimeyer. 1999). Tapi ternyata korelasi antara religiusitas dan death anxiety pada subjek lansia tidak berhasil ditemukan (Fortner \& Neimeyer, 1999).

Orientasi religiusitas sebagai salah satu aspek yang paling besar memiliki korelasi dengan death anxiety menjadi logis. Orientasi religius didefinisikan oleh Worthington (Natalia \& Wirawan, 2004) sebagai suatu cara pandang mengenai kedudukan agama dalam hidupnya yang menentukan pola bentuk relasi individu dengan agamanya dan ditambahkan oleh Worthington bahwa orientasi religius menjelaskan peranan agama dalam kehidupan seseorang. Menurut Allport dan Ross (Natalia \& Wirawan, 2004) orientasi religius dibagi menjadi dua yaitu instrinsik dan ekstrinsik. Orientasi instrinsik mengarahkan seseorang untuk menghayati agama sebagai sesuatu yang bemilai bagi diri sendiri dan menuntut keterlibatan dan mengatasi kepentingan dirinya. Selain itu orientasi instrinsik juga telah mengorbankan dan mengurangi hal-hal yang bersifat duniawi dan mencari hal-hal yang Ilahiah termasuk hal-hal yang berhubungan dengan kematian. Orang-orang dengan orientasi instrinsik akan memandang kematian sebagai suatu sarana untuk bertemu dengan Tuhan. Oleh karenanya, individu tidak akan mengalami kecemasan dengan kematiannya.

Salah satu dimensi religiustas yang dikemukakan Glock dan Stark (Uyun, 1998) adalah dimensi ideologis (religious belief). Hal ini mengacu pada seberapa tingkat keyakinan seseorang terhadap kebenaran agamanya, terutama berkaitan dengan ajaran-ajaran yang fundamental dan dogmatis. Percaya pada kehidupan setelah mati merupakan salah satu bentuk ajaran fundamental dan dogmalis dalam sebuah agama. Manakala seseorang memiliki keyakinan yang kuat dengan kehidupan setelah mati, tentunya individu akan menjadi yakin terhadap kematiannya. Oleh karena itulah individu tersebut akan memiliki kecemasan terhadap kematian yang rendah.

Demikian juga dengan dimensi ritual yang dikemukakan Glock dan Stark, bahwa ritual mengacu pada seberapa tingkat kepatuhan seseorang dalam mengerjakan kegiatan-kegiatan ritual sebagaimana dianjurkan oleh ajaran agamanya. Aspek ini memiliki korelasi dengan death anxiety yang lebih rendah dibandingkan percaya pada kehidupan setelah mati. Hal ini menjadijelas, dengan memahami bahwa seseorang yang memiliki keyakinan yang kuat akan hari kebangkitan, cenderung memiliki penghayatan agama yang lebih kuat dibandingkan dengan seseorang yang sekedar menjalankan ritual. Karena seseorang yang menjalankan ritual agamanya belum tentu memilik: penghayatan yang besar terhadap agamanya. Bisa saja ritual yang dijalankan hanya sekedar formalitas dalam menjalankan agamanya. Tetapi ada juga individu yang benar-benar menjalankan ritual agamanya dengan penuh kesadaran. Rítual semacam inllah yang kemungkinan dapat berdampak tehadap penurunan kecemasan terhadap kematian.

\section{PENUTUP}

Berdasarkan meta analisis yang dilakukan ternadap variabel religiusitas dan death anxiety didapat kesimpulan bahwa secara umum religiusitas berkorejasi negatif 
dengan death anxiety. Artinya bahwa semakin tinggi religiusitas seseorang, maka semakin rendah death anxiety-nya. Demikian sebaliknya. Dari kelima aspek religlusitas, empat aspek dapat dipercaya berkorelasi negatif dengan death anxiety, yaitu orientasi religius irstrinsik, pentingnya beragama, ritual, dan percaya pada hidup sesudah mati sedangkan pada aspek tingkat religiusitas tidak bisa disimpukan apakah tingkat religiusitas berkorelasi dengan death anxiety. Hal itu dikarenakan tidak diketahuinya batas bawah nilai estimasi korelasi populasinya.

\section{DAFTAR PUSTAKA}

Chung, M. C., Chung, C. and Easthope, $Y$. 2000. Traumatic Stress and Death Anxiety among Community Residents Exposed to an Aircraft Crash. Death Studies, 24(8), 689-704.

Cicirelli, V. G. 1998. Personal Meanings of Death in Relation to Fear of Death. Death Studies, 22(8), 713-733.

Florian, V. and Mikulincer, M. 1997. Fear of Personal Death in Adulthood: The Impact of Early and Recent Losses. Death Studies, 21(1), 1-24.

Fortner, B.V. and Neimeyer, R. A 1999. Death Anxiery in Older Adults: A Quantitative Review. Death Studies, $23(5), 387-411)$.

Hunter, J. E. and Schmidt, F. L. 1990. Methods of Meta-Analysis: Correcting Error and Bias in Research Findings. Newbury Park, California: Sage Publications. Inc.

Natalia, P. and Wirawan, H. E. 2004. Orientasi Religius Pasangan Dewasa Muda Kristen yang Mengalami Ketidakharmorisan Pernikahan. Jurnal IImiah Psikologi "ARKHE", 9(2), 82-89.
Uyun, Q. 1998. Religiusitas dan Motif Berprestasi Mahasiswa. Psikologika, 6(3), 45-51.

Referensi yang digunakan untuk studi meta analysis:

Duff, R. W. and Hong, L. H. 1995. Age Density, Religiosity and Death Anxiety in Retirement Communities. Review of Religious Research, 37, 19-32.

Falkenhein, M. and Handal. P. J. 2003. Religion, Death Attitudes, and Belief in Afterlife in the Elderly: Untangling the Relationships. Joumal of Religion and Health, 43 (1), 67-76.

Harding, S. R., Flannelly, K. J., Weaver, A. J., and Costa, K G. 2005. The Influence of Religion on Death Anxiety and Death Acceptance. Mental Health, Religion \& Culture, 8 (4), 253-261.

Roff, L L., Butkeviciene, R., and Klemmack, D. L. 2002. Death Anxiety and Religioisity among Lithuanian Health and Social Service Professionals. Death Studies, 26, 731-742.

Suhail, K, and Akram, S. 2002. Correlates of Death Anxiety in Pakistan. Death Studies, 26, 39-50.

Swanson, J. L. and Byrd. K. R. 1998). Death Anxiety in Young Adults as a Function of Religious Orientation, Guilt, and Separation-Individuation Conflict. Death Studies, 22, 257-268.

Wink, P. and Scott, J. (2005). Does Religiousness Buffer Against the Fear of Death and Dying in Late Adulthood? Findings from a Longitudinal Study. Journal of Gerontology: Psychological Sciences, 60B (4), P207-P214. 